\title{
受光量最大化のための太陽光パネル最適設置に関する検討 Study on Optimum Installation of Solar Panels to Maximize the Amount of Light Received
}

\author{
○学 入佐 佳史（信州大）学 金子 聖司（信州大院） 正 中村 正行（信州大）
}

Yoshifumi IRISA, Shinshu University, 4-17-1 Wakasato, Nagano City, Nagano

Seiji KANEKO, Graduate School of Shinshu University, ditto

Masayuki NAKAMURA, Shinshu University, ditto

Key Words: Optimization, Photovoltaic Panels, Shade, Solar Radiation, Installation

\section{1. はじめに}

太陽光発電は，発電パネルを屋根や壁に取り付けること が容易であり，一般家庭への普及が増大している。太陽光 発電パネルの設置方法には Fig.1のように固定型, 追尾型, 集光型等がある ${ }^{(1)(2)}$ が，コストや設置スペースの問題があ るため一般家庭には固定型が普及している。

一方で，固定設置された太陽光パネルにはいくつかの課 題がある.まず, 影によってパネルへの入射量が減少する.

Fig.2 に示寸ように太陽光パネルの近くに樹木や建物等の 障害物があると太陽光が遮られて発電量が低下寸る。周囲 の環境によっては, 真南にパネルを設置せず, 周りの障害 物による影響を考慮して設置場所および角度を設計するこ とで発電量を最大化できる。また，地域に適した設置角度 が存在する。地軸の傾きにより 1 年を通して太陽の軌道が 変化する.さらに夏には大気中の水蒸気量が多く, 散乱に より日射量が低下するとともに太陽光パネルの温度が上昇 するので発電効率が低下する，そのため，太陽光パネルの 向きや角度および設置場所を 1 年を通して影を考慮して発 電量が最大となるように最適化することで, 固定型におい ても発電量の増加が期待できる.

本研究では, 太陽光パネルの日射量を増加させるために, 太陽光パネル設置場所での太陽の軌道と障害物によってで きる日影および入射角等に依存する日射量を解析し，最適 な設置場所の設計を行うことを目的とする。 まず，設置地 域の緯度と経度および日時から，太陽の軌道を計算する。 太陽の軌道より，太陽光線が障害物にあたり太陽光パネル に投影される影を, 光線追跡により求める. また, 日射量 は, 法線面直達日射量および散乱日射量を考慮して, 両者 を加えた水平面日射量を求める。 また，水平面日射量は気 象庁の過去のデータを使用することで設置場所の 1 年間〜 数年間の気象を考慮する。

\section{2. 日射量の解析}

影の位置を計算するために，太陽高度角と太陽方位角を 求める. 太陽高度角 $h$ と太陽方位角 $\gamma$ は以下の式で表わさ れる。

$$
\begin{aligned}
& \sin h=\sin \phi \sin \delta+\cos \phi \cos \delta \cos \omega \\
& \sin \gamma=\cos \phi \sin \omega / \cos h
\end{aligned}
$$

$\phi$ は緯度， $\delta$ は太陽赤緯， $\omega$ は時角を表している. 水平面 日射量 $I_{H T}$ は, 法線面直達日射量 $I_{N D}$ と散乱日射量 $I_{S}$ の 和で表わされる.

$$
I_{H T}=I_{N D}+I_{S}
$$
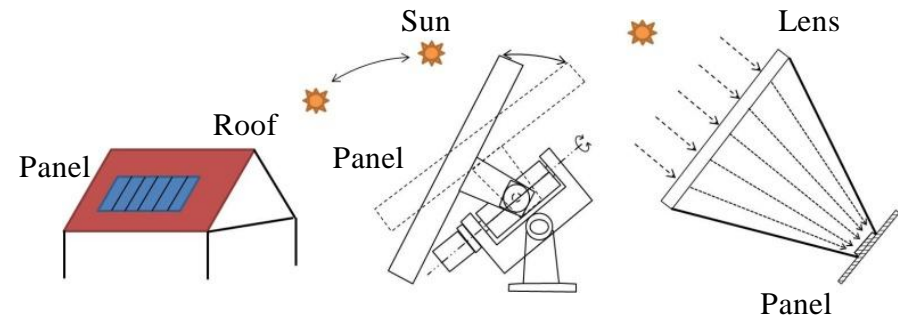

Fig.1 Installation types of solar panel

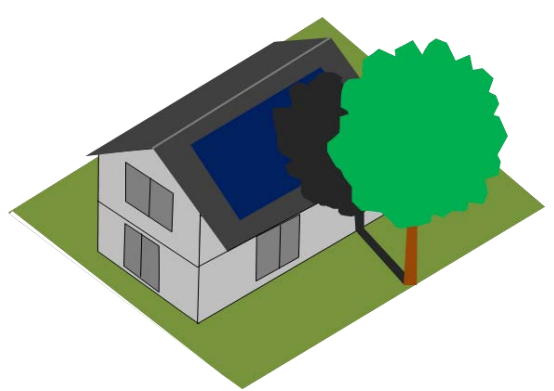

Fig.2 Shade on a solar panel

法線面直達日射量は次式で表わされる.

$$
I_{N D}=I_{0} P^{1 / \sinh }=I_{0} P^{\operatorname{cosec} h}
$$

$I_{0}$ は太陽定数である.ここでは，太陽定数を $1367 \mathrm{~W} / \mathrm{m}^{2}$ と する．P は大気透過率である，散乱日射量は，天候や雲の 様子によって大きく変化するが，晴天日の散乱日射量は次 に示す Berlage の式によって求めることができる ${ }^{(2)}$.

$$
I_{S}=\frac{I_{0} \sinh \left(1-P^{1 / \sin h}\right)}{2(1-1.4 \ln P)}
$$

\section{3. 影の解析 \\ 3.1 光線追跡}

影の動きを捉える上で光線追跡の手法を用いる．木など の任意形状を持つ障害物は外形形状を離散化して考える.

Fig.3 に障害物と影を表すための座標を示す. Fig.3 に示す ように木などの障害物表面を 3 角形平面に分割する。これ ら 3 角形 $i$ の中心座標を $\mathrm{O}\left(x_{0}{ }^{i}, y_{0}{ }^{i}, z_{0}{ }^{i}\right)$, その影で太陽パネ ルが遮られた時の投影 3 角形 $i$ の中座標を $\mathrm{P}\left(x_{p}{ }^{i}, \mathrm{y}_{p}{ }^{i}, \mathrm{z}_{p}{ }^{i}\right)$ とする.このときの光源である太陽の位置は $\mathrm{S}(h, \gamma)$ とする. 光源からの法線ベクトル $\boldsymbol{n}_{\boldsymbol{s}}\left(l_{s}, m_{s}, n_{s}\right)$ は, 太陽高度角 $h$ と 
太陽方位角 $\gamma$ より次式で与えられる.

$$
\boldsymbol{n}_{\boldsymbol{s}}(\cot h \cos \gamma, \cot h \sin \gamma, \operatorname{cosec} h \sin \gamma)
$$

\section{2 隠面処理}

式 (6)により,影が移動する際の座標を求めることができ る. 影が太陽光パネルに重なっているかどうかの判定には 隠面処理による内包判定を用いる. 隠面処理の中でも奥行 き座標の大きさによってその面が視点から前方にあるか後 方にあるかを判定する $z$ バッファ法を用いる．奥行き座標 の值が小さい場合，それは手前の面にあると判定できる. 逆に，奥行き座標が大きい場合は遠い位置にある。最も手 前にある面の面積を求めることで時間的な重なりが判定で きる。

\section{4. 解析例}

Fig.4に，影を考慮して太陽光パネルへの日射量を求める ための例題におけるパネルと建物の上面図, 正面図, 右側 面図を示す，長野市において $a \times b=5 \mathrm{~m} \times 6 \mathrm{~m}$ のパネルを南方 向に設置し，高さ $l=15 \mathrm{~m}$, 幅 $W=1 \mathrm{~m}$ の障害物が南西方向にあ ると仮定したときの日射量をFig.5に示寸. $c=5 \mathrm{~m}, d=2 \mathrm{~m}$ とした. Fig.5のグラフから，午後には影がパネルにかかっ ているため，日射量が減少しているのが分かる，午前中に は影がパネルにかからないためその場所における最大の日 射量を受光できる. 発電量が大きい南中高度付近の12時〜 14時に影がかかっており, この配置は不利である.同様に， 障害物を南東方向に設置した場合をFig.6に示す．グラフよ り午前中から午後にかけて影がかかっている様子がわかる.

\section{6. おわりに}

本研究は, 日射量を求めるために太陽高度角と太陽方位 角を太陽軌道から求め, 移動する影の面積を光線追跡と隠 面処理の手法を用いて求めた。 太陽光パネルに影がかかっ た際の日射量の変化を求めることができた．また，緯度や 設置角度など様々な条件を変えることで日射量の総量に変 化が見られた. 今後, 太陽光パネルの設置角度や方向, 設 置位置をパラメータとした最適化を行う。

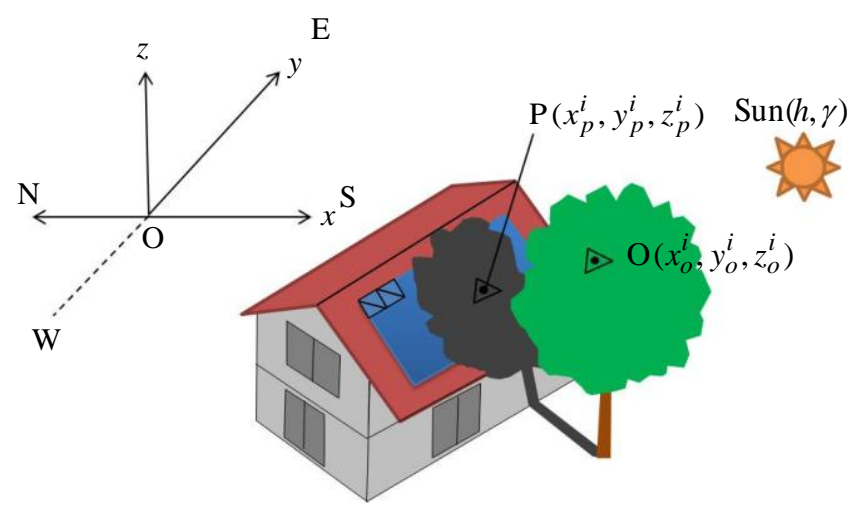

Fig.3 Coordinates of an obstacle and it's shade
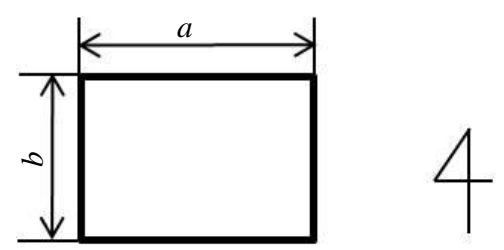

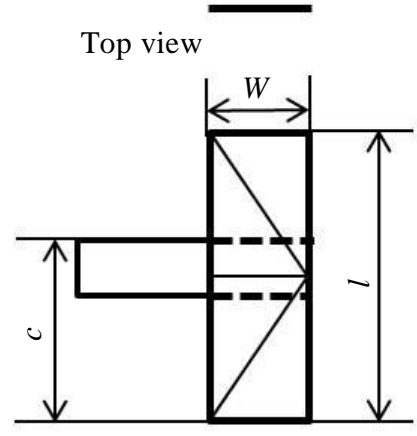

Front view

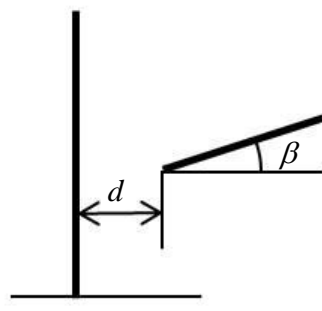

Side view
Fig.4 Configuration of panel and obstacle

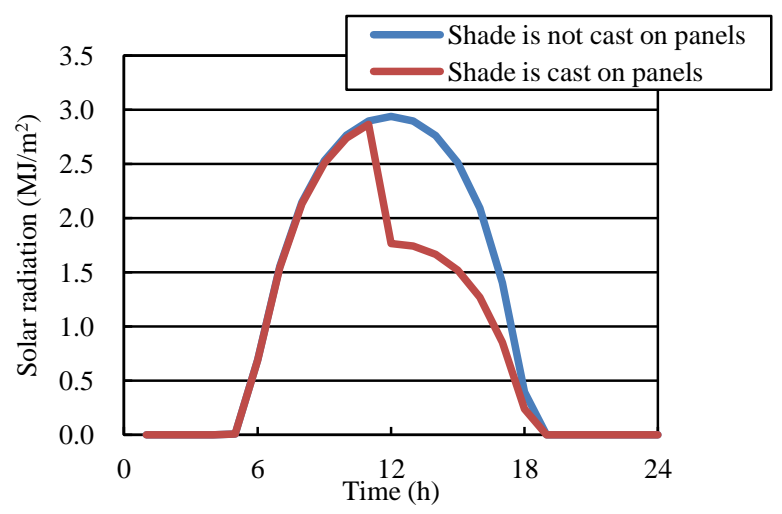

Fig.5 Solar radiation to the panel installed in the direction of south-west

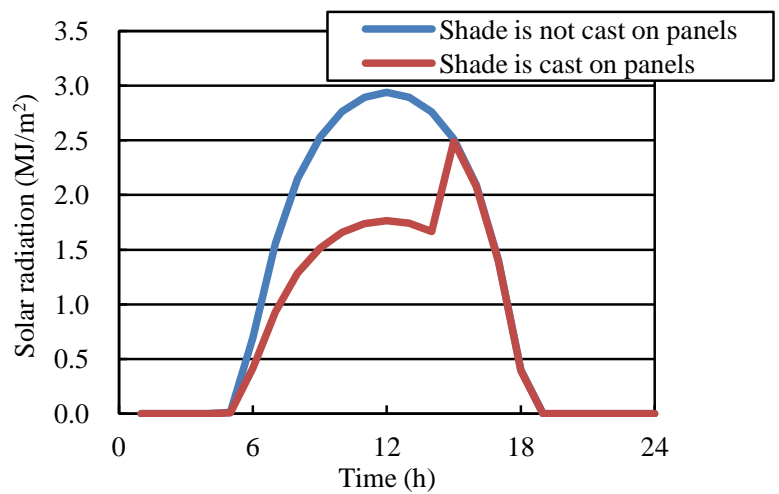

Fig.6 Solar radiation to the panel installed in the direction of south-east

\section{参考文献}

(1) 化学工学会, 図解 新エネルギーの寸べて (改訂版), 工 業調査会, (2009), pp.7-68.

（2）金山公夫，馬場 弘，ソーラーエネルギー利用技術, 森北出版, (2004), pp.26-31.

(3) John A Duffie, William A. Beckman, Solar Engineering of Thermal Processes, Wiley, (2006), pp.3-40. 